\title{
Lactobacillus paracasei probiotic properties and survivability under stress-induced by processing and storage of ice cream bar or ice-lolly
}

\section{André Fioravante Guerra ${ }^{1,5^{*}} \odot$ Wilson José Fernandes Lemos Junior ${ }^{2}$ Geraldo Oliveira dos Santos ${ }^{3}$ Christian Andrighetto $^{4}$ Alessio Gianomini ${ }^{2}$ Viviana Corich ${ }^{2}$ Rosa Helena Luchese ${ }^{5}$}

${ }^{1}$ Centro Federal de Educação Tecnológica Celso Suckow da Fonseca, 27600 000, Valença, RJ, Brasil. E-mail: andrefioravanteguerra@gmail.com. ${ }^{*}$ Corresponding author.

${ }^{2}$ Dipartimento di Agronomia Animali, Alimenti, Risorse Naturali e Ambiente. Università degli Studi di Padova, Legnaro, Italia.

${ }^{3}$ Departamento de Microbiologia, Instituto Fernandes Figueira, Fundação Oswaldo Cruz (Fiocruz), Rio de Janeiro, RJ, Brasil.

${ }^{4}$ Veneto Agricoltura, Istituto per la Qualità e le Tecnologie Agroalimentari, Thiene (VI), Italia

${ }^{5}$ Departamento de Tecnologia de Alimentos, Instituto de Tecnologia, Universidade Federal Rural do Rio de Janeiro (UFRRJ), Seropédica, RJ, Brasil.

ABSTRACT: Probiotics are live microorganisms which, when administered in adequate amounts, confer a health benefit on the host. The aim of this study was to identify genotypically lactobacilli strains isolated from newborn stools and selecting strain based on probiotic properties (gastrointestinal tolerance, antibiotic susceptibility, inhibition of pathogen biofilm formation, absence of alfa or gamma-blood hemolysis, and lysozyme sensibility) and technological properties of surviving either in ice cream bar or ice-lolly. Reduction of $1.2 \mathrm{log}$ cfu ml ${ }^{-1}$ of the Lactobacillus paracasei strain was observed after exposure through in vitro gastrointestinal conditions. It inhibited biofilms of Escherichia coli, Salmonella Typhimurium and Candida albicans by mechanisms of competition, exclusion and displacement, and was resistant up to $3000 \mu \mathrm{g} \mathrm{ml-1}$ of egg white lysozyme. It presented neither alfa nor gamma-hemolysis or was antibiotic resistant to usual antibiotics for human use. Microbial survivability in ice cream bar or ice-lolly was assessed up to 21 days of storage at $-18^{\circ} \mathrm{C}$. Viability was maintained in ice cream bar, but there was a reduction of almost 2.0logs in ice-lolly.

Key words: frozen dessert, functional food, probiotic strain.

Propriedades probióticas e sobrevivência de Lactobacillus paracasei sobre estresse induzido pelo processamento e armazenamento em picolé a base de leite ou água

RESUMO: Probióticos são microrganismos vivos que, quando administrados em quantidade adequadas, conferem beneficios à saúde do hospedeiro. O objetivo desta pesquisa foi identificar genotipicamente lactobacilos isolados de material fecal de recém-nascidos, assim como selecionar uma cepa com base em suas propriedades probióticas (tolerância às condições gastrointestinais, susceptibilidade à antibióticos, inibição da formação de biofilmes por microrganismos patogênicos, ausência de hemólise alfa ou gama e sensibilidade à lisozima) e tecnológicas de sobrevivência em picolé à base de água ou leite. Houve redução de 1,2log ufc ml-1 do isolado identificado como Lactobacillus paracasei após passagem pelas condições gastrointestinais in vitro. Esta cepa inibiu a formação de biofilmes de Escherichia coli, Salmonella Typhimurium e Candida albicans pelos mecanismos de competição, exclusão e desacoplamento e apresentou resistência até $3000 \mu \mathrm{g}$ ml ${ }^{-1}$ frente a lisozima de ovo. Entre os aspectos de segurança, a cepa não apresentou hemólise alfa ou gama e não foi resistente a antibióticos comumente ministrados em humanos. A sobrevivência microbiana em picolé a base de água ou leite foi analisada ao longo de 21 dias de estocagem a $-18^{\circ} \mathrm{C}$. Houve manutenção da viabilidade no produto à base de leite, mas naquele à base de água, ocorreu redução de quase 2,0logs.

Palavras-chave: sobremesa láctea, alimento funcional, probiótico.

\section{INTRODUCTION}

Lactobacillus species are reported in environments rich in available carbohydrate substrates such as vegetables and milk sources, but also in human and animal cavities (CAMPANARO et al., 2014). Lactobacillus paracasei species are commonly used in probiotic dairy products; such as yogurt, cheese, fermented milk, and ice cream (STEFANOVIC et al., 2017).
Ice cream is a frozen dairy obtained by freezing the ice cream mix with continuous agitation. It is manufactured with or without addition of other ingredients and substances, such as fruit pulp or juice, to improve the quality and sensory characteristics. In addition, frozen desserts products can be made without dairy ingredients by freezing the homogenous or non-homogeneous mixture of food ingredients, with or without air incorporation, 
and maintained under these conditions during storage, transport, and delivery for consumption (DEOSARKAR et al., 2016).

Dose levels of probiotics should be based on levels reported to be efficacious in human studies (GANGULY et al., 2011; AKALIN et al., 2017). In a more advanced approach, it shows that when probiotics are intended for gut benefits, they shall survive the passage through the gastrointestinal tract. Foods are good probiotic matrices, since they are consumed daily by humans and animals (LEE et al., 2015; VILLALVA et al., 2017) and yoghurt and ice cream are important vehicles to convey several beneficial to lactic acid bacteria strains (EVIVIE et al., 2017). But stressinduced by processing and storage of ice cream bar or ice-lolly can reduce probiotic survivability and the minimum dose cannot be target. Consequently, it is important to select specific strains to be used in ice cream; furthermore, there are few specific commercial strains available to this aim.

The aim of this research was to select the best probiotic Lactobacillus out of 35 strains from human origin, identify them genotypically and to evaluate some probiotic properties and technological capability to survive in ice cream bar or ice-lolly.

\section{MATERIALS AND METHODS}

\section{Isolation and characterization of Lactobacillus} strains

Lactobacilli strains were isolated from infant's stools aged between 7 to 21 days, assisted by the Human Milk Bank (HMB), by the Neonatal Intensive Care Unit (NICU) from Fernandes Figueira Institute of FIOCRUZ and by the HMB from Rocha Faria State Hospital, all located in Rio de Janeiro.

Genotypic identification of lactobacilli by sequencing of the $16 \mathrm{~S} r D N A$ region

DNA of isolated colonies on MRS agar (Oxoid, Basingstoke, United Kingdom) was extracted with $50 \mu 1$ of lysis solution $(0.25 \%$ SDS and $\left.0.05 \mathrm{~mol}^{-1} \mathrm{NaOH}\right)$. After mixing for 60 seconds, the mixture was treated at $95^{\circ} \mathrm{C}$ for $15 \mathrm{~min}$ in a thermocycler (T100, Bio Rad, Italy) for cell lysis, followed by centrifugation to $10.500 \mathrm{~g}$ for 10 minutes (5427 R Centrifuge, Eppendorf). Volumes of $10 \mu \mathrm{L}$ of supernatants were diluted in $90 \mu 1$ of ultrapure water for molecular biology (Sigma-Aldrich) and used as a template for PCR (Polymerase Chain Reaction).
Reaction mixtures for PCR contained dNTPs (Invitrogen), 200 $\mu \mathrm{mol}$ $\mathrm{l}^{-1}$; "AGAGTTTGATCCTGGTCAG" and "AAGGAGGTGATCCAGCCGCA" primers (MWG Biotech), $1 \mu \mathrm{mol} \mathrm{l}^{-1}$; Taq Polymerase (Amersham), $1 \mathrm{U}$; DNA template, $2 \mu \mathrm{l}$ of diluted lysate; ultrapure water for molecular biology (Sigma-Aldrich) to complete a final volume of $25 \mu 1$.

Reaction was initiated with hot start and after a common one cycle initial denaturation step $\left(94^{\circ} \mathrm{C}, 300 \mathrm{~s}\right)$, the amplification program was: 35 cycles at $94^{\circ} \mathrm{C}$ for $30 \mathrm{~s} ; 56^{\circ} \mathrm{C}$ for $30 \mathrm{~s} ; 72^{\circ} \mathrm{C}$ for $60 \mathrm{~s}$, and a single final extension step $72^{\circ} \mathrm{C}$ for 300 s.

Subsequently, $10 \mu \mathrm{l}$ of PCR product was mixed with $10 \mu \mathrm{l}$ of bromophenol blue buffer and applied to agarose gel using 1.2\% TAE (TrisAcetate EDTA) as running buffer. The run started at $80 \mathrm{v}$ for 5 minutes, followed by $100 \mathrm{v}$ for 40 minutes. The gel was then immersed in ethidium bromide solution $\left(10 \mathrm{mg} \mathrm{ml}^{-1}\right)$ for 1 hour and photographed in a gel documentator (LAS Image Quanti 500, GE Healthcare Life Science, UK). After checking the amplification, the PCR product was dried in the thermal cycler at $50^{\circ} \mathrm{C}$ for 10 minutes and sequenced as described by ANDRIGHETTO et al., (2001).

The sequences of the $16 \mathrm{~S}$ rDNA region were subjected to a BLAST search against the nucleotide database in NCBI. Results of the sequences were confirmed using RAPD-PCR analysis.

\section{RAPD-PCR analysis \\ RAPD-PCR analysis for DNA} extraction, strains were grown overnight in MRS broth (Himedia, Mumbai, India). The DNA was extracted with lysis solution $(0.25 \%$ SDS and $\left.0.05 \mathrm{~mol} \mathrm{l}^{-1} \mathrm{NaOH}\right)$. Amplification reactions were performed according with ANDRIGHETTO et al., (2001). Amplification products were separated by electrophoresis on agarose gel $\left(15 \mathrm{~g} \mathrm{l}^{-1}\right)$ in $0.5 \mathrm{x}$ TBE buffer $\left(0.45 \mathrm{mmol} \mathrm{l}^{-1}\right.$-Tris- $\mathrm{HCl}, 0.45 \mathrm{mmol} \mathrm{l}^{-1}$ boric acid, 1mmol $\mathrm{l}^{-1}$ EDTA, $\mathrm{pH} 8.3$ ). Cluster analysis of RAPD-PCR profiles (Figure 1) were analysed using the Gel Compar software version 4.1 (Applied Maths, Kortrijk, Belgium).

\section{Tolerance to challenges miming gastrointestinal transit Strain resistance under in vitro} gastrointestinal conditions was tested as previously described by FAVARIN et al. (2015) with some modifications as changing in the time of residence in each condition: 45 minutes into gastric conditions (3.5 $\mathrm{g} \mathrm{l}^{-1}$ swine mucin, $0.26 \mathrm{~g} \mathrm{l}^{-1}$ swine pepsin, $\mathrm{pH} 2.0$ ) and 180 minutes into intestinal condition $\left(3.0 \mathrm{~g} \mathrm{l}^{-1}\right.$ 


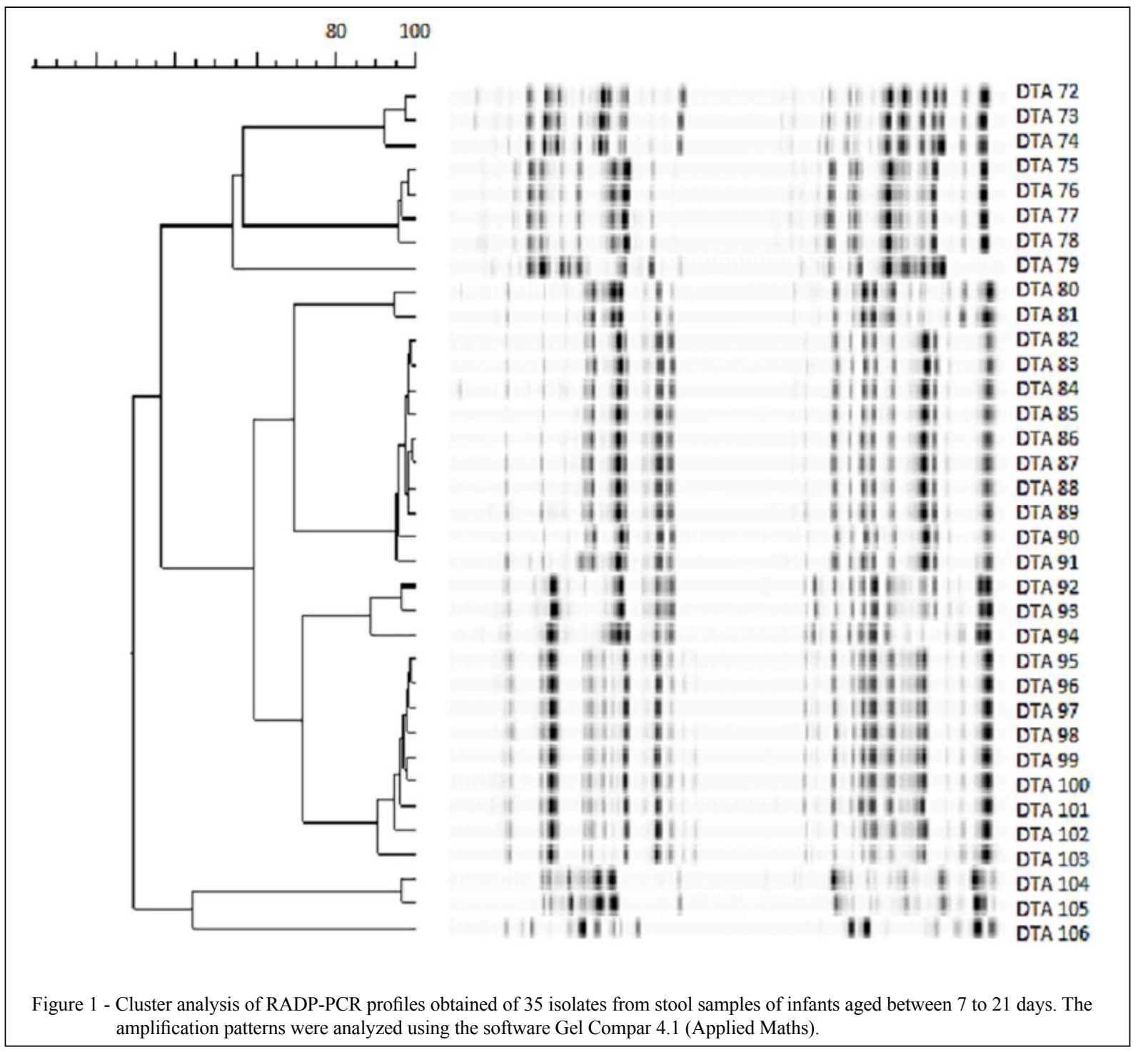

ox-bile; $1.95 \mathrm{~g} \mathrm{l}^{-1}$ pancreatin, $0.1 \mathrm{~g}^{-1}$ lysozyme, $\mathrm{pH}$ 7.0).Viable lactobacilli were enumerated after each condition by drop technique on MRS agar (HiMedia, Mumbai, India) with incubation at $36^{\circ} \mathrm{C}$ for 48 hours.

\section{Antibiotic susceptibility assay}

Antibiotic susceptibility of the strains was evaluated by agar disk diffusion (ADD) as described by BAUER et al. (1966) using MRS agar (HiMedia, Mumbai, India). Lactobacilli inoculum ( $\mathrm{ca} 10^{6} \mathrm{cfu} /$ $\mathrm{ml}$ ) was spread on the agar surface with a Drigaslky spreader. Dried discs (CECON, São Paulo) impregnated with seven distinct antibiotics for human use: amoxicillin + clavulanic acid (AMC); ciprofloxacin
(CIP); cephalexin (CFX); chloramphenicol (CLO); tetracycline (TET); ampicillin (AMP); and nalidixic acid (NAL) were distributed on the agar. Plates were incubated at $36^{\circ} \mathrm{C}$ for 48 hours and the diameter of growth inhibition zones surrounded the discs were measured with a caliper (including disc).

Results were expressed as resistant $(\varnothing \leq$ $15 \mathrm{~mm})$, intermediate $(16>\varnothing<20 \mathrm{~mm})$, or sensitive $(\varnothing \geq 20 \mathrm{~mm})$ in accordance to what was proposed by VLKOVÁ et al. (2006).

Lysozyme resistance assay

Lyso-plate method, with Micrococcus luteus (ATCC 4698; INCQS 356) as indicator 
microorganism, was used to measure lysozyme activity. Melted MRS agar (Himedia, Mumbai, India) was inoculated with a fresh suspension of either the indicator microorganism or the isolated strain to a final concentration of approximately $10^{6} \mathrm{cfu} \mathrm{ml}^{-1}$ and plated in Petri dishes. Five wells were dug in each plate with a sterile manual borer $(6.8 \mathrm{~mm})$ and filled with 100 , $400,800,1500$ or $3000 \mu \mathrm{g} \mathrm{ml}^{-1}$ of egg white lysozyme (Sigma-Aldrich, S. Louis, Mo, USA) solutions previously filter sterilized $(0.22 \mu \mathrm{m})$. After incubation at $36^{\circ} \mathrm{C}$ for $48 \mathrm{~h}$, the diameter of inhibition halo formed from the well border was measured with a caliper. Results were statistically analyzed by 2 -way analysis of variance (ANOVA) followed by Fischer's test with $95 \%$ of reliable using XLSTAT software version 7.5.

\section{Pathogen biofilm inhibition assay}

Potential of lactobacilli to prevent pathogenic biofilm formation (Salmonella Typhimurium and Candida albicans) or potential food-borne pathogenic biofilms (Escherichia coli ATCC 25922) raised on hydrophobic surface of polystyrene microtiter plate of 96 wells flat bottom was assessed using the technique described by WOO \& AHN (2013). Lactobacilli were challenged to prevent three different mechanisms of biofilm formation: competition, exclusion, and displacement. The mono specie cultures of pathogenic bacteria were used as controls. Enumeration of biofilm cells after a swab of the well was performed by drop plate technique plating cell suspensions of Escherichia coli, Salmonella Typhimurium, and Candida albicans on Eosin Methylene Blue agar (HiMedia, Mumbai, India), Hecktoen Enteric agar (Himedia Mumbai, India), and Sabouraud agar (Oxoid, Basingstoke, United Kingdom), respectively.

\section{Hemolysis on blood agar}

Lactobacilli cultures were screened for hemolytic activity by streaking on MRS agar (HiMedia, Mumbai, India) added with 5 $\%$ defibrinated sheep blood (Eurofarma, Rio de Janeiro, Brazil) and by stabbing into the agar to encourage any anaerobic version of the enzymes to digest blood cells. After incubation at $36^{\circ} \mathrm{C}$ for 48 hours the medium was inspected for $\alpha$-hemolysis (gray-green halo) and $\beta$-hemolysis (transparent halo).

Probiotic culture survival in ice cream bar and ice-lolly Ice-lolly was made by mixing in a blender, $31.80 \%$ of mineral water at $5^{\circ} \mathrm{C}$ with ice (1:1), $40.00 \%$ of frozen acerola pulp (Ice Fruit-
Rio, Brazil), $27.10 \%$ of sugar, $1.00 \%$ of probiotic inoculum, $0.02 \%$ of red coloring, and $0.08 \%$ of

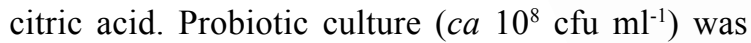
added at the last step. It was shaped and frozen in a quick-freezing machine.

Ice cream bar was made by mixing $33.00 \%$ of powdered milk (Tangará Foods S/A, Brazil), 33.00\% of frozen acerola pulp (Ice-FruitRio, Brazil), $16.50 \%$ of sugar, $14.36 \%$ of mineral water at $5^{\circ} \mathrm{C}$ with ice $(1: 1), 1.86 \%$ of neutral bind (guar and xanthan gum, corn starch, anti-mixer and carboxymethylcellulose), $1.00 \%$ of probiotic inoculum, $0.19 \%$ of turmeric dye, and $0.09 \%$ of emulsifier. It was shaken and processed in ice cream machine for 15 minutes.

Ten kilograms of each type of frozen dessert were prepared and the lactobacilli survivability were enumerated up to 21 days of storage at $-18^{\circ} \mathrm{C}$ by drop plate technique on MRS agar (HiMedia, Mumbai, India) with incubation at $36^{\circ} \mathrm{C}$ for 48 hours.

\section{RESULTS AND DISCUSSION}

A pool of 35 Lactobacillus sp. strains isolated from infant's stool without antibiotictherapy history were organized into nine different genetic profiles (Table 1) which can be observed by the ramifications and percentages of similarity among the strains present in the phylogenetic tree. The RAPD-PCR method was suitable to give information on the genetic relationship between these strains, determining the variability among Lactobacillus species and within the same species, which were confirmed by $16 \mathrm{~S}$ conserved genome zone sequencing. This achievement of identification and intraspecific differentiation of Lactobacillus species by the RAPD-PCR technique was also observed in studies conducted by ANDRIGHETTO et al. (2001), and TSAFRAKIDOU et al. (2016). Probiotics from human origin can developed better in human biome (RAVISHANKAR \& RAI, 2015). However, this attribute is not enough to guarantee the probiotic safety. Three essential safety attributes were considered in this study, (1) isolated from newborn without antibiotic-therapy history, (2) absence of hemolytic activity, (3) and high antibiotic susceptibility.

The best probiotic strain from 35 strains of lactobacilli (Lactobacillus paracasei DTA 83) was taken for further technological assays in ice cream bar or ice-lolly. This strain presented a high rate of survivability after exposure through in vitro gastrointestinal conditions (Figure 2A), as compared 
Table 1 - Group lactobacilli strains isolated from feces of infants aged between 7 to 21 days.

\begin{tabular}{|c|c|}
\hline Genetic profiles & Strains \\
\hline 1 & DTA $72,73,74$ (L. rhamnosus) \\
\hline 2 & DTA $75,76,77,78$ (L. rhamnosus) \\
\hline 3 & DTA 79 (L. rhamnosus) \\
\hline 4 & DTA 80,81 (L. paracasei) \\
\hline 5 & DTA $82,83,84,85,86,87,88,89,90,91$ (L. paracasei) \\
\hline 6 & DTA $92,93,94$ (L. paracasei) \\
\hline 7 & DTA $95,96,97,98,99,100,101,102,103$ (L. paracasei) \\
\hline 8 & DTA 104, 105 (L. fermentum) \\
\hline 9 & DTA 106 (L. fermentum) \\
\hline
\end{tabular}

with others Lactobacillus strains (data not shown). After passage through artificial gastric and intestinal juices there were 0.5 and 1.2 decimal reductions (DR), respectively.

Regarding lysozyme resistance, Lactobacillus paracasei DTA 83 was not inhibited up to $400 \mu \mathrm{g} \mathrm{ml}^{-1}$ of lysozyme. From $800 \mu \mathrm{g} \mathrm{ml}^{-1}$ to $3000 \mu \mathrm{g} \mathrm{ml}^{-1}$, a slight inhibition was observed, but significantly lower as compared with the sensible indicator Micrococcus luteus (Figure 2B). Lysozyme resistance is an important probiotic characteristic since this enzyme is present in the gastrointestinal juice at concentration of $100 \mu \mathrm{g} \mathrm{ml}^{-1}$ and is also used as a preservative in food technology. Therefore, the concentration of lysozyme present in intestinal juice will not affect the survivability of Lactobacillus paracasei DTA83.

Lactobacillus paracasei DTA 83 reduced adhesion and biofilm formation by gut pathogenic or potential food-borne pathogenic by competition and exclusion (more than $2 \operatorname{logs}$ of reduction of Escherichia coli and Candida albicans), and displacement (approximately $1 \log$ of reduction) (Figure 3). Lactobacillus paracasei DTA 83 probably has prophylactic and therapeutic effect over undesirable microorganism biofilms, but it is worth to note that these were in vitro assays conducted on microtiter plates made of polycarbonate plastic surfaces, instead of intestinal epithelium villi cells.

Regarding safety aspects, out of nalidixic acid (NAL), Lactobacillus paracasei DTA 83 was sensitive to all antimicrobials tested (Table 2). Lactobacillus paracasei DTA 83 did not have alpha or gamma-hemolysis on blood agar. This property is desirable for probiotic microorganisms. Pathogenic microorganisms can cause hemolysis in the blood.

Technological properties such as microbial survivability during the processing and storage of ice cream bar or ice-lolly are shown in figure 4. In ice cream bar (milk based), there was no reduction on the viability of Lactobacillus paracasei DTA 83, but in ice-lolly (water based), there was almost $2 \operatorname{logs}$ of reduction. Milk protects Lactobacillus during freezing/storage and acidity from the acerola. Probiotic ice cream in milkbased carrier is satisfactory to maintain viability of Lactobacillus paracasei at dose levels above 6 logs/g standardized by WHO (2006) and specific Brazilian law (BRAZIL, 2015).

LEE et al. (2015) investigated the contributions of milk to the health-benefiting performance of Lactobacillus casei BL23 in a dextran sulfate sodium induced murine model of ulcerative colitis. L. casei BL23 protected against the development of colitis when ingested in milk but not in a nutrient-free buffer simulating consumption as a nutritional supplement. The authors concluded that carrier matrices for probiotic bacteria should; therefore, be carefully selected and optimized to ensure the highest levels of probiotic survival and effector production in the digestive tract.

Losses in the viability of probiotic bacteria in ice cream unavoidably occur during product formulation, processing, storage, and melting. During these steps, probiotic cells are subjected to different stresses related to $\mathrm{pH}$, acidity, redox potential, freezing, oxygen (especially in overrun step), sugar concentration and osmotic effects, hydrogen peroxide, and mechanical shearing. It seems that the rate of loss of probiotic 


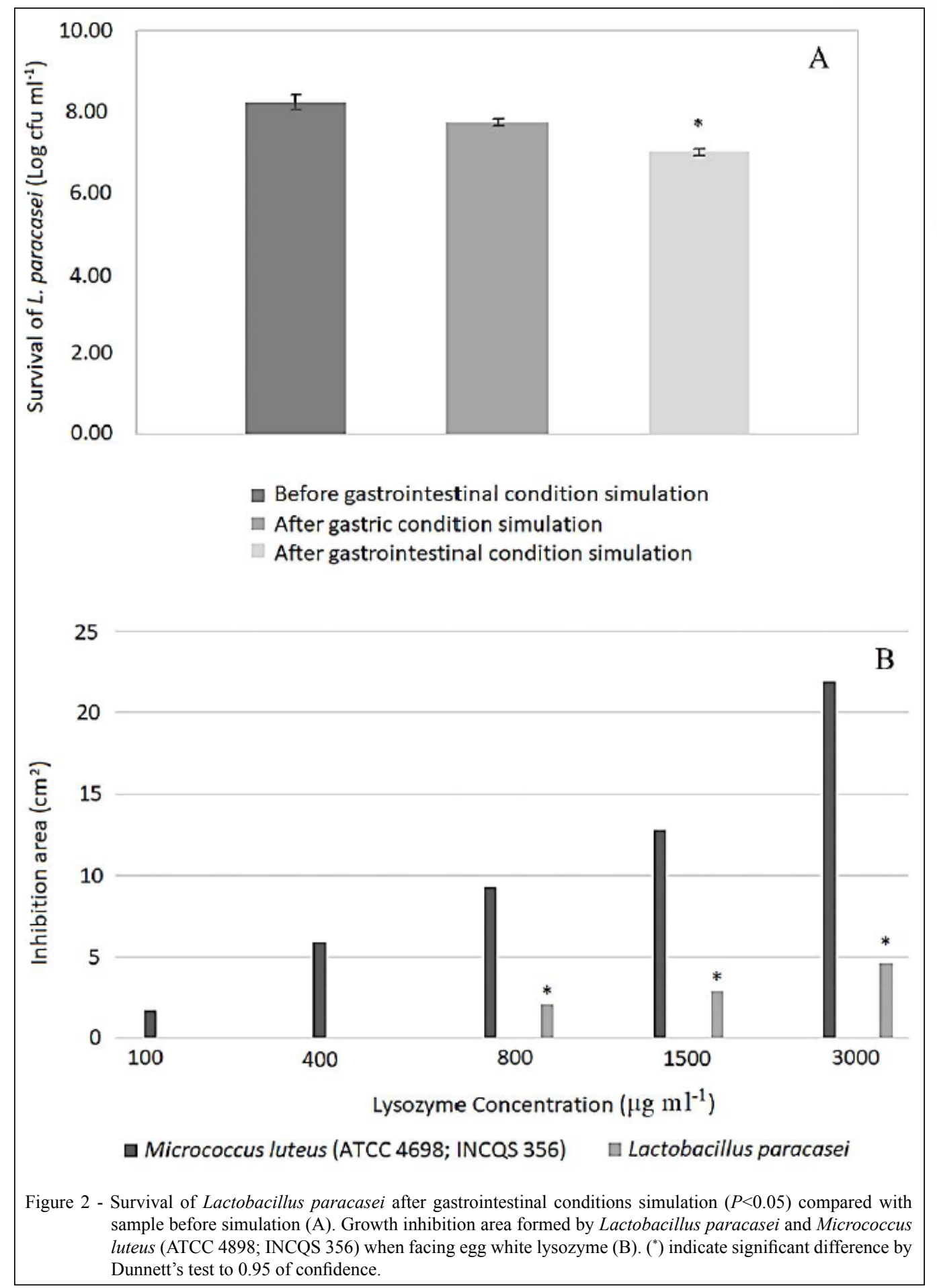

cells is greater during the freezing process than during storage (MOHAMMADI et al., 2011). Acerola (Malpighia emarginata) is an acid fruit, with high content of vitamins (mainly vitamin
C), anthocyanins, flavonoid, minerals such as magnesium, iron, and calcium (FERNANDES et al., 2011). Its antioxidant activity favors probiotic bacteria, and its acidity, in this case, apparently did 


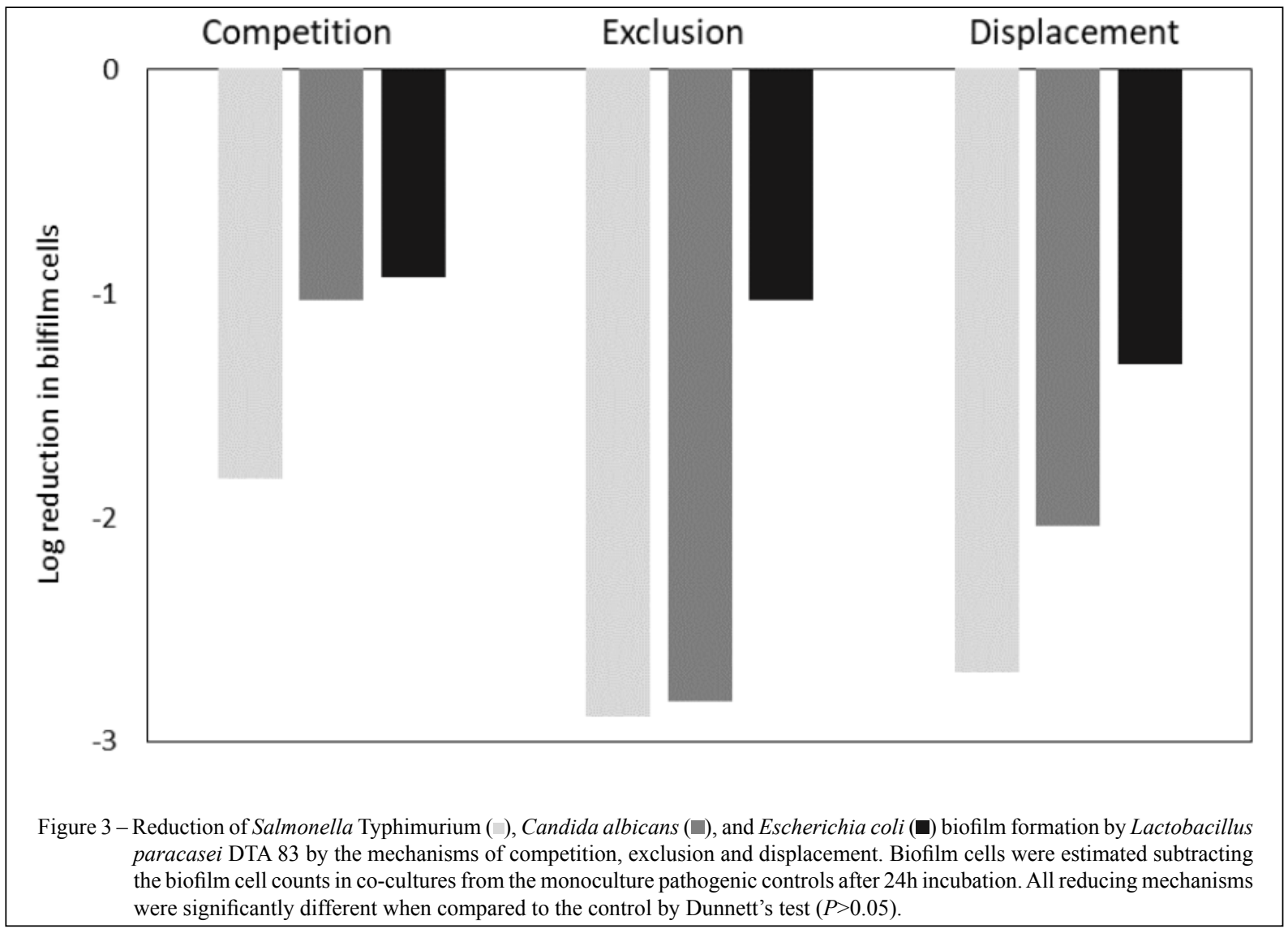

not have the deleterious effect of freezing. During the crystallization process, the milk or water base can produce different structure at low temperature (PARK et al., 2015). Lactobacillus paracasei survive better in ice cream bar, especially due to milk fat that protects the microorganism during crystallization at low temperature (HAMOSH et al., 1999).

\section{CONCLUSION}

Lactobacillus paracasei DTA 83 has satisfactory probiotic properties but there are limitations to be used in probiotic ice cream. Only ice cream bar (milk base) guarantees the strain survivability up to 21 days of storage $\left(-18^{\circ} \mathrm{C}\right)$.

Table 2 - Susceptibility of Lactobacillus paracasei DTA 83 to antibiotics for human use.

\begin{tabular}{lc}
\hline Antibiotics & Diameter halo (mm) \\
AMP & $54.35 \pm 2.23 \mathrm{~S}$ \\
AMC & $48.00 \pm 11.31 \mathrm{~S}$ \\
CLO & $44.55 \pm 6.15 \mathrm{~S}$ \\
TET & $36.00 \pm 0.00 \mathrm{~S}$ \\
CFX & $33.45 \pm 2.05 \mathrm{~S}$ \\
CIP & $29.55 \pm 2.90 \mathrm{~S}$ \\
NAL & $6.00^{*} \pm 0.00 \mathrm{R}$ \\
\hline
\end{tabular}

S - Sensitive; I - Intermediate; R - Resistant; $\left(^{*}\right)$ - disc diameter. 


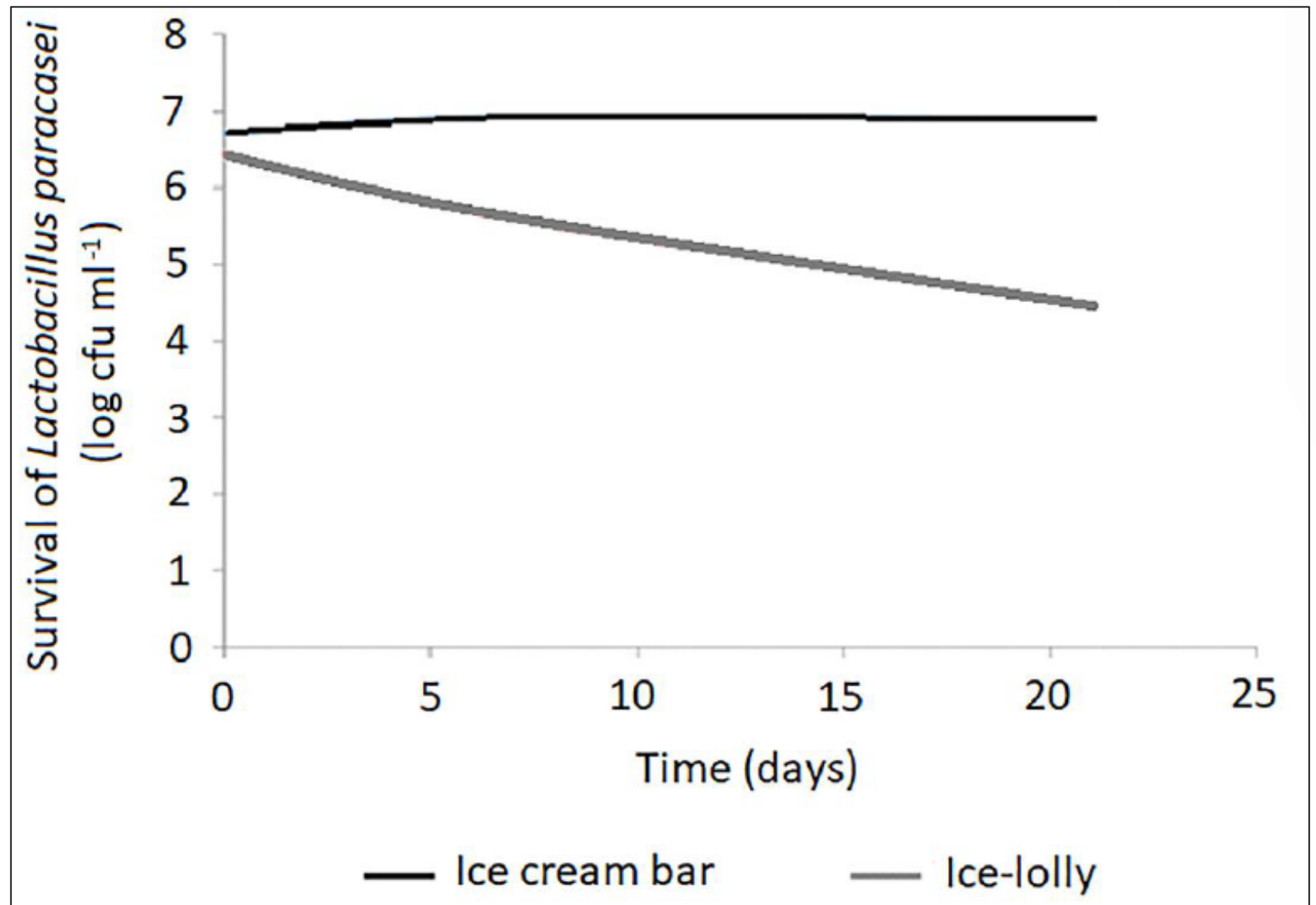

Figure 4 - Survival of Lactobacillus paracasei DTA 83 in ice cream bar or in ice-lolly for up 21 days of storage at $-18^{\circ} \mathrm{C}$.

\section{ACKNOWLEDGEMENTS}

This research was supported by Coordenação de Aperfeiçoamento de Pessoal de Nível Superior (CAPES).

\section{DECLARATION OF CONFLICTING INTERESTS}

The authors declare no conflict of interest. The founding sponsors had no role in the design of the study; in the collection, analyses, or interpretation of data; in the writing of the manuscript, and in the decision to publish the results.

\section{REFERENCES}

AKALIN, A. S., et al. Enrichment of probiotic ice cream with different dietary fibers: Structural characteristics and culture viability. J Dairy Sci, 2017. doi: 10.3168/jds.2017-13468.

ANDRIGHETTO, C., et al. RAPD-PCR characterization of lactobacilli isolated from artisanal meat plants and traditional fermented sausages of Veneto region (Italy). Letters in Applied Microbiology, v.33, n.1, p.26-30. 2001. Available from: <http://
dx.doi.org/10.1046/j.1472-765X.2001.00939.x>. Accessed: Jul. 14, 2017. doi: 10.1046/j.1472-765X.2001.00939.x.

BRAZIL. Resolução ${ }^{\circ} 18$. IX-Lista de Alegações de Propriedade Funcional Aprovadas. Anvisa. Brasília: Diário Oficial da União DOU - da República Federativa do Brasil 2015.

CAMPANARO, S., et al. Metagenomic analysis of the microbial community in fermented grape marc reveals that Lactobacillus fabifermentans is one of the dominant species: insights into its genome structure. Appl Microbiol Biotechnol, v.98, n.13, p.601537. 2014. doi: 10.1007/s00253-014-5795-3.

DEOSARKAR, S. S., et al. Ice Cream: Uses and Method of Manufacture. In: (Ed.). Encyclopedia of Food and Health. Oxford: Academic Press, 2016. Ice Cream: Uses and Method of Manufacture, p.391-397.

EVIVIE, S. E., et al. Some current applications, limitations and future perspectives of lactic acid bacteria as probiotics. Food Nutr Res, v.61, n.1, p.1318034. 2017. doi: 10.1080/16546628.2017.1318034.

FAVARIN, L., et al. Survival of free and microencapsulated Bifidobacterium: effect of honey addition. Journal of Microencapsulation, v.32, n.4, p.329-335. 2015. Available from: 
$<$ http://dx.doi.org/10.3109/02652048.2015.1017620>. Accessed: Jul. 20, 2017. doi: 10.3109/02652048.2015.1017620.

FERNANDES, F. A. N., et al. Drying of Exotic Tropical Fruits: A Comprehensive Review. Food and Bioprocess Technology, v.4, n.2, p.163-185. 2011. Available from: < http://dx.doi.org/10.1007/ s11947-010-0323-7>. Accessed: Jul. 14, 2017. doi: 10.1007/ s11947-010-0323-7.

GANGULY, N. K., et al. ICMR-DBT Guidelines for Evaluation of Probiotics in Food. The Indian Journal of Medical Research, v.134, n.1, p.22-25. 2011. Available from: <http:/www.ncbi.nlm. nih.gov/pmc/articles/PMC3171912/>. Accessed: Jul. 20, 2017.

HAMOSH, M., et al. Protective function of human milk: the milk fat globule. Semin Perinatol, v.23, n.3, p.242-9. 1999.

LEE, B., et al. Attenuation of Colitis by Lactobacillus casei BL23 Is Dependent on the Dairy Delivery Matrix. Applied and Environmental Microbiology, v.81, n.18, p.64256435. 2015. Available from: <http://www.ncbi.nlm.nih.gov/ pmc/articles/PMC4542224/>. Accessed: Jul. 14, 2017. doi: 10.1128/AEM.01360-15.

MOHAMMADI, R., et al. Probiotic ice cream: viability of probiotic bacteria and sensory properties. Annals of Microbiology, v.61, n.3, p.411-424. 2011. Available from: <http://dx.doi.org/10.1007/ s13213-010-0188-z>. Accessed: Jul. 14, 2017. doi: 10.1007/ s13213-010-0188-Z.

PARK, S. H., et al. Effect of Frozen Storage Temperature on the Quality of Premium Ice Cream. Korean Journal for Food Science of Animal Resources, v.35, n.6, p.793-799. 2015. Available from:
<http://www.ncbi.nlm.nih.gov/pmc/articles/PMC4726959/>. Accessed: Jul. 14, 2017. doi: 10.5851/kosfa.2015.35.6.793.

RAVISHANKAR, V. R.; A. B. RAI. Microbes in fermented and functional foods. New York: CRC Press, v.1. 2015. 511 p.

STEFANOVIC, E., et al. Advances in the genomics and metabolomics of dairy lactobacilli: A review. Food Microbiol, v.61, p.33-49. 2017. doi: 10.1016/j.fm.2016.08.009.

TSAFRAKIDOU, P., et al. Technological, phenotypic and genotypic characterization of lactobacilli from Graviera Kritis PDO Greek cheese, manufactured at two traditional dairies. LWT - Food Science and Technology, v.68, p.681-689. 2016. Available from: <http:// www.sciencedirect.com/science/article/pii/S0023643816300020>. Accessed: Jul. 20, 2017. doi: 10.1016/j.lwt.2016.01.002.

VILLALVA, F. J., et al. Formulation of a peach ice cream as potential symbiotic food. Food Science and Technology, v.37, p.456-461. 2017. Available from: <http:// www.scielo.br/scielo.php? script $=$ sci_arttext\&pid $=$ S0 101 $20612017000300456 \&$ nrm=iso $>$. Accessed: Jul. 14, 2017.

VLKOVÁ, E., et al. Antimicrobial susceptibility of bifidobacteria isolated from gastrointestinal tract of calves. Livestock Science, v.105, n.1, p.253-259. 2006. Available from: <http://dx.doi. org/10.1016/j.livsci.2006.04.011>. Accessed: Jul. 14, 2017. doi: 10.1016/j.livsci.2006.04.011.

WHO. Probiotics in Food - Health and Nutrition Properties and guidelines for evaluation. Health and Nutrition Properties of Probiotics in Food including Powder Milk with Live Lactic Acid Bacteria. Fao. Rome: FAO and WHO 20062006. 